\title{
喉頭全摘出術と頸部郭清術
}

\author{
名古屋大学医学部耳鼻咽喉科 \\ 藤 本 保 志
}

表 1 病期以外の治療方針決定要因

・手術をするとしたら

・喉頭直達鏡下手術が可能か

·部分切除 /半切除が可能か

·永久気管孔の要否

・化学療法が可能か

・腎機能, 心機能, 肝機能 $\cdots$

・要求される声の質, 治療期間

·職業, 家庭環境

- 合併症 /既往症

・放射線治療の既往

・脳梗塞の既往／誤嚥性肺炎の既往

はじめに

喉頭全摘術後は確実な気道確保（安全な呼吸と嚥下） が得られ, 現代でも進行喉頭癌に対する治療として重要 であるが，近年は化学療法・放射線治療の進歩や喉頭温 存手術の普及により治療方針が多様化し，早期癌は放射 線治療, 進行癌は喉頭全摘との二分ではなくなった。

\section{1. 標準治療}

米国からは NCCN ガイドライン1)，拈よび米国国立が ん研究所 (National Cancer Institute) の PDQ (Physician Data Query）が公開されている. 本邦でも頭頸部癌診 療ガイドライン ${ }^{2)}$ が作成され，改訂第 2 版が出版された ので是非とも参照されたい. どのガイドラインもすべて のステージに対して $2 \sim 3$ の選択肢が示される. 本邦の ガイドラインでは T4でも手術を先行するか，化学放射 線治療を先行するかの 2 つ選択肢が準備される. NCCN では声門上癌と声門癌に分けられ，T4では手術 が推奨され，T4に対する化学放射線治療は手術を希望 しない場合のみである。また， T3 では手術先行，化学 放射線治療，化学療法先行による振り分けの 3 つの選択
肢が示される，選択の基準は病期以外に求めざるを得な いが，表 1 に示すような因子を考慮することとなる.

\section{2. 喉頭癌に対する頸部郭清術}

かつて頸部郭清術は下顎下縁から鎖骨上までのリンパ 節を含む組織を根こそぎ郭清するものであったが，内頸 静脈や副神経，胸鎖乳突筋の温存に始まり，次に郭清領 域を省略するようになり，術式が多彩となった，表 2 に 厚生労働省がん研究班会議岸本班において提唱された下 咽頭癌および声門上癌の頸部郭清術のガイドラインを示 す.ここではAmerican Academy of OtolaryngologyHead and Neck Surgery(AAO-HNS) が2002年に提唱し だ)ものに準拠したレベル分類と, Japan Neck Dissection Study Group ${ }^{4)}$ により提案された方法を併記した. NCCN ガイドラインの概要は予防郭清としてレベル IIIV（ND $(\mathrm{j}))$ ，声門下癌に対してレベル VI（ND $(j, p t) ）$ の追加が推奨され, 転移陽性側では全領域 (comprehensive neck dissection）または selective，両側郭清の適応 は舌根, 声門上, 特に喉頭蓋前隙浸潤である. 
表 2 厚生労働省がん研究班 岸本班による下咽頭癌／声門上癌頸部郭清ガイドラインより改変

\begin{tabular}{|c|c|c|}
\hline \multirow[b]{2}{*}{ T1-3 N0 } & 患側 & レベル II, III, IV の範囲; $\mathrm{ND}(\mathrm{J})$ の予防的頸部郭清術 \\
\hline & 健側 & $\begin{array}{l}\text { 原発巣の進展範囲に応じて症例ごとに判断するが, 明らかに正中を超える場合 } \\
\text { は最低限レベル II ， III， IV ; ND (J) の郭清を行う. }\end{array}$ \\
\hline T4N0 & & 個々で病態が異なるため, 郭清範囲は症例ごとに判断する \\
\hline \multirow{2}{*}{$\begin{array}{l}\text { any } \mathrm{T} \text { N1 } \\
\text { any } \mathrm{T} \text { N2a }\end{array}$} & 患側 & レベル I を除く全頸部郭清 : ND(JP) \\
\hline & 健側 & $\begin{array}{l}\text { 原発巣の進展範囲に応じて症例ごとに判断するが, 明らかに正中を超える場合 } \\
\text { は最低限レベル II， III， IV ; ND }(\mathrm{J}) \text { の郭清を行う. }\end{array}$ \\
\hline \multirow{2}{*}{ any $\mathrm{T} N 2 \mathrm{~b}$} & 患側 & $\begin{array}{l}\text { レベル I を除く全頸部郭清：ND(JP), ただし転移個数が多い場合は顎下部郭 } \\
\text { 清を追加することももる. }\end{array}$ \\
\hline & 健側 & $\begin{array}{l}\text { 原発巣の進展範囲に応じて症例ごとに判断するが, 明らかに正中を超える場合 } \\
\text { は最低限レベル II ， III， IV ; ND }(\mathrm{J}) \text { の郭清を行う. }\end{array}$ \\
\hline $\begin{array}{l}\text { any } \mathrm{T} \text { N2c } \\
\text { any } \mathrm{T} \text { N3 }\end{array}$ & & 個々で病態が異なるため, 郭清範囲は症例ごとに判断する \\
\hline
\end{tabular}

表 3 現代の喉頭全摘術の適応

\begin{tabular}{|c|}
\hline 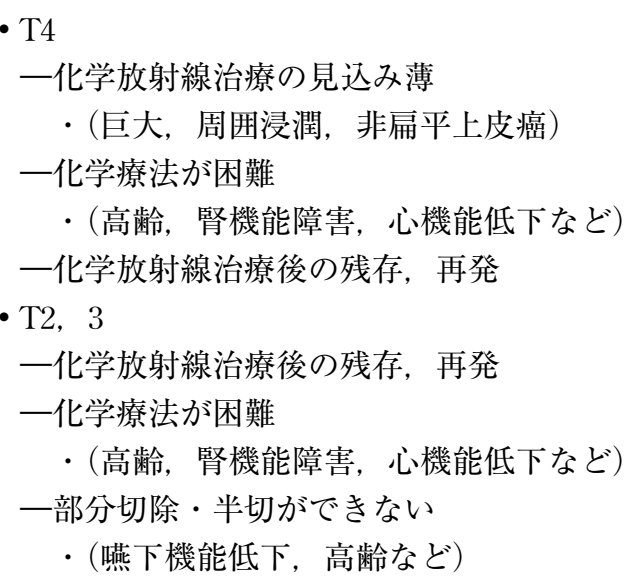 \\
\hline
\end{tabular}

\section{3. 喉頭全摘術のピットフォール}

今や喉頭全摘術の適応（表 3 ）は簡単には切除しにく いか (隣接臓器), 創が治りにくいか (放射線治療後), 全身状態が悪いかのいずれかに当てはまる。ピットフォ ールの理解が安全性を高める.

\section{$\mathrm{a}$ : 隣接臓器浸潤への対処}

軟骨に囲まれた枠組みを単純にとる意識では危険であ る. 隣接臓器 (下咽頭梨状陥凹, 気管, 甲状軟骨) 浸潤 に加え, 喉頭蓋谷 - 舌根, 甲状舌骨膜, 喉頭蓋前隙, 傍 声帯間隙, 披裂部から輪状後部, 輪状甲状膜などへの浸 潤の程度を把握する。詳細な内視鏡観察と thin-slice の 造影 CT が有用である．たとえば，傍声带間隙浸潤症例 では甲状軟骨裏面の剥離操作中に腫瘍を露出させやす
く, 喉頭蓋前隙浸潤例では舌骨直上から喉頭蓋谷へ向か う切除において腫瘍が近い. 一方, 舌根合併切除症例で は舌動脈や舌下神経の温存に留意する。

b：化学放射線治療後再発例での合併症軽減

・頸部皮弁の血流

化学放射線治療後の前頸部皮膚は色素沈着を認め, 柔 軟性を失っている。これは放射線治療後の組織血流不全 や線維化によるが, 皮膚切開線の選択において皮弁挙上 後の血流を意識する必要がある．頸部郭清が両側必要な 場合はU字切開が選択されるが，皮弁先端の血流不全 （図 1 ）に留意が必要である. Hocky stick や J 字切開で も対側の領域郭清は可能である(図 2 )。挙上した皮弁は 濡らしたガーゼで覆い, 愛護的に扱うことも忘れない. 
〔スキルアップ講座

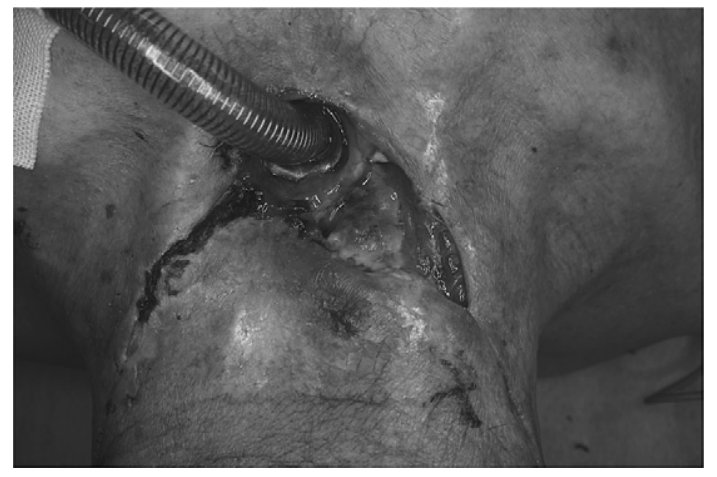

図 $1 \quad \mathrm{U}$ 字皮虐切開後の前頸部皮弁壊死

化学放射線治療後再発例に対して両側頸部郭清術・喉頭全摘術を行った，術直後 より皮弁の色調が悪く，壊死に陥ったため再手術にて DP 皮弁再建を行った.

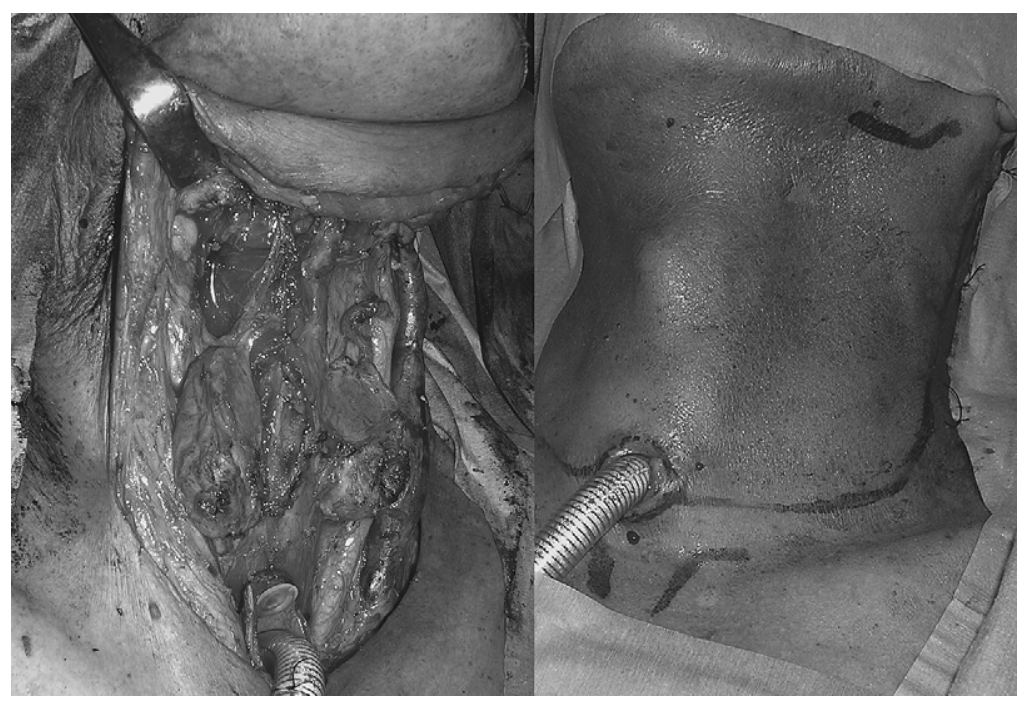

図 2 Hockey Stick Incision

頸部皮弁血流を考慮した皮虐切開．図の症例では左はレベル $I I-V ，$ 右はレベル II-IVの郭清を行った.

\section{・縫合不全対策}

喉頭癌ではほとんどが一期縫縮可能であるが，化学放 射線治療後は残存粘膜の血流も悪いため, 縫合部に緊張 がかからない縫合が優先される．場合により大胸筋皮弁 や，場合によっては下咽頭も合併切除して遊離空腸移植 を選択すれば照射野外での縫合が可能である。また，全 身状態不良例などでは外瘻形成も安全な対策の一つであ る.

\section{4. 喉頭全摘を受ける患者への対応}

\section{$\mathrm{a}$ ：障害の階層構造}

1980年に制定された WHO 国際障害分類（ICIDH ; International Classification of Impairments, Disabilities, and Handicaps）では, 生活の問題を機能形態的障害, 能力障害, 社会的不利の 3 層に分類した. 2002年に改訂 された国際生活機能分類）（ICF）に準拠しつつ喉頭全 摘術後障害を整理し図 3 に示す．喉頭全摘では術後障害 が術前からはっきり分かるため, 術前からのリハビリテ ーションの視点が重要である. 術後の音声, 嗅覚の再獲 得訓練, 代償法の説明や, 音声訓練の患者会への参加な どを锥める．また，喉頭全摘後は身体障害者認定（音声 機能） 3 級申請が必須である，医療費減免，電気喉頭の 購入補助等に役立つ.

b : 機能回復 · 再獲得への方策

音声再獲得法には食道発声, 電気喉頭の他, シャント 発声が有力である，気管食道瘻を造設し，永久気管孔を 


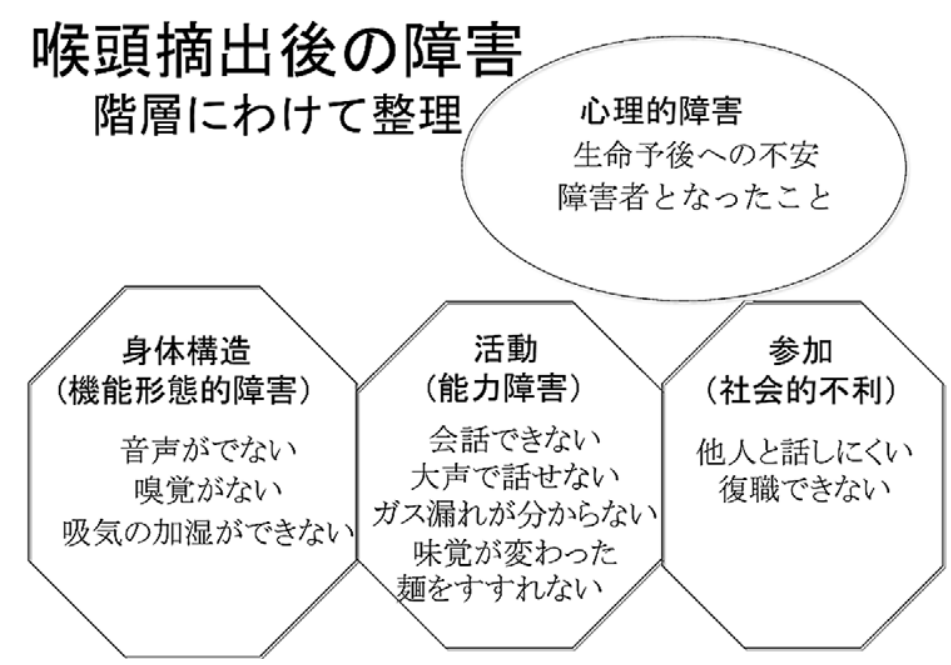

図 3 喉頭摘出後の障害の階層構造

ICF（国際生活機能分類）および ICIDH（国際障害分類：international classification of impairment）に準拠して整理した.

用手閉鎖して呼気を咽頭へ導き，発声する。誤嚥防止を 手術的に目指す天津法などと，人工弁を用いる方法があ る. 食道発声よりも最大発声持続時間が長く, 獲得率が 高い $(80 \%$ 前後).

c：永久気管孔一鼻呼吸の喪失

永久気管孔により鼻呼吸も峦失する．吸気の加温，加 湿が不可能となり, 特に冬期, 吸気の加湿や吸入療法の 指導が重要である。咱覚障害は訓練が可能である.

Hilgers は随意的に口腔咽頭を陰圧にして吸気を鼻腔に 導くNasal Airflow-Inducing Manuber : NAIM 法 ${ }^{6)}$ を提 唱している.

$$
\text { ま と め }
$$

喉頭癌に対する喉頭全摘・頸部郭清術の適応の概説と 手術の留意点, 術後の機能障害への対応について述べ た。手術・リハビリテーションともに手術前の計画が大 切である。

\section{参考文献}

1) National Comprehensive Cancer Network: http :// www. nccn. org / professionals / physician_gls / f guidelines.asp\#site (2012.4.1).
2) 頭頸部癌診療ガイドライン2013版. 日本頭頸部癌学会 編，金原出版；2013.

3) Robbins KT, Clayman G, Levine PA, et al : American Head and Neck Society; American Academy of Otolaryngology-Head and Neck Surgery : Neck dissection classification update: revisions proposed by the American Head and Neck Society and the American Academy of Otolaryngology-Head and Neck Surgery. Arch Otolaryngol Head Neck Surg 2002; 128 : 751-758.

4) Hasegawa Y, Saikawa M: Update on the classification and nomenclature system for neck dissection : revisions proposed by the Japan Neck Dissection Study Group. Int J Clin Oncol 2010； 15 : 5-12.

5）ICF 国際生活機能分類一国際障害分類改訂版一。障害者 福祉研究会 編, 中央法規; 2002 .

6) Hilgers FJ, van Dam FS, Keyzers S, et al : Rehabilitation of olfaction after laryngectomy by means of a nasal airflow-inducing maneuver : the "polite yawning" technique. Arch Otolaryngol Head Neck Surg 2000 ; 126 : 726-732.

連絡先 テ466-8550 名古屋市昭和区鶴舞町65 名古屋大学医学部耳鼻咽喉科 藤本保志 